\title{
Management Styles as Element of Shaping Company Organizational Culture
}

\author{
Dominika Strycharska, Marzena Ogórek \\ Czestochowa University of Technology, Poland
}

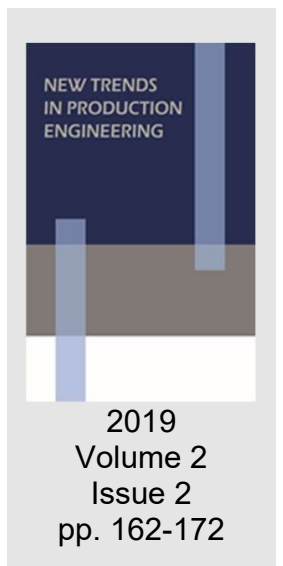

Date of submission to the Editor: 09/2019

Date of acceptance by the Editor: 11/2019

\section{INTRODUCTION}

The changes taking place in enterprises and their surroundings determine new approaches to management, including the perception of the role of employees. An important group of employees is managers, who are a key resource in every enterprise; the way it functions and its effectiveness depends on them (Srivastava \& Agrawal, 2010; Rolková \& Farkašová, 2015).

Effective management styles are constantly being sought, but so far nobody has dared to indicate which of the many possible to apply is the most effective. Knowledge combined with experience allow one to make the best management decisions for a given situation. It is emphasized that the choice of the management style which may be appropriate in practice, depends on the situation. Therefore, knowledge of the ability to recognize the conditions in which a task is to be performed and to predict the effects of using the possible styles to choose from is important (Cieślicki, 2001).

An increase in interest in organizational culture occurring in enterprises is observed. Organizations associate people and are based on the activities of these people, therefore it is important to learn about and shape cultural patterns and link specific elements of cultures characteristic for each organization. Management staff has a significant contribution in shaping organizational culture. Behaviors and the management styles used by the management staff are observed by employees and influence the shaping of cultural patterns in the enterprise (Stańczyk, 2008; Olmedo-Cifuentes \& Martinez-Léon, 2014; Luthans \& Stajkovic, 1999).

Attempts to find universal management methods, various human resources, as well as the currently observed business trend based on recognizing the role and importance of organizational culture for the functioning of enterprises and, above all, the lack of knowledge in the subject literature on the topic of the impact of organizational culture on managing the diversity of human resources in organizations leads to researchers' interest in the discussed subject (Chmielewska-Muciek 2009; Kostera et al. 1998; Sikorski 2006). 


\section{MANAGEMENT STYLES}

The effectiveness of exercising power in an organization is demonstrated, among others, by how the management executes its functions, which is connected not only with the competences it has, but also with the use of a particular management style. The factors that have a significant impact on the selection of a particular management style by the management staff are personality traits as the internal conditions of an individual and external factors that affect the construction of relational capital (Kocher et al., 2013).

The concept of management style should be understood as "a relatively permanent and repeatable way of a supervisor influencing subordinates to stimulate and coordinate their team activities aimed at achieving the goals facing the organization" (Penc, 1997).

It can be assumed that management styles depend on the personal characteristics of the manager. It is also important that the management style of senior managers is copied or duplicated by lower level managers. This means that the style represented by the top management at the highest level exerts a decisive influence on the work of the entire organization (Penc, 2000).

Thus, management styles are elements of the management system, understood as all the organizational, institutional and functional solutions that implement a specific vision of the enterprise's vision, as well as the way of managing people and the enterprise. The management style largely determines the efficient and effective operation of the institution. By using appropriate management styles, managers can influence the job satisfaction, commitment and productivity of employees (Walecka, 2013; Kim, 2002).

According to Hortoványi (2012, p. 43), enterprising companies distinguished by their ability to innovate, initiate changes and react quickly to changes are companies in which senior managers are characterized by entrepreneurial management styles (Hortoványi, 2012).

Management styles differ among one another in types, combinations of connections and the means of motivation used, which influence the behavior of subordinates in order to achieve the assumed goals. Adequate selection and stimuli are important in management. The management style largely determines the efficient and effective operation of the institution (Żukowski \& Galla, 2009). The research conducted by scientists on management styles allowed several concepts to be distingished regarding the behavior of the manager, which in turn led to the creation of many theories on management style. The literature on the subject presents many different approaches to this problem. The classical division of management styles includes autocratic, democratic and liberal style (Kieżun, 1997).

\section{ORGANIZATIONAL CULTURE}

Organizational culture is recognized as an important factor in the success of modern enterprises. By creating values, norms and attitudes, it primarily affects the relations within the organization as well as its identity and image. It sets out 
the directions, goals and related activities relevant to the functioning of enterprises (Panasiewicz, 2013).

The conscious creation of an organizational culture with which employees identify themselves enables them to engage in work and allows managers to better manage the team and thus achieve the intended goals of the organization (Panasiewicz, 2013; Zehir et al., 2011).

Organizational culture understood as the so-called "personality of a specific enterprise" or "certain invisible property" is a network of meanings, values and organizational norms - it "programs the minds" of the organization's members (Kostera et al., 1998; Chmielewska-Muciek, 2009; Cameron \& Quinn, 2006; Schein, 2004).

Among the main components of the organization, apart from the strategy and structure, organizational culture stands out, which is influenced by many factors. According to D. Drennam, they are: the influence of dominant leaders, company history and traditions, technologies, products and services, customers, company expectations, the information and control system in force in the company, company legislation and environment, the system of penalties and rewards used in the enterprise, organization and company resources, as well as the goals, values and beliefs of employees (Perechuda, 2000; Tohidi \& Jabbari, 2012).

An important role in shaping the organizational culture is played by managers employed in the organization by promoting a specific system of cultural management values. Therefore, it is important for managers to be aware of what cultural patterns of employee behavior are particularly desirable for the organization's success, how to shape and consolidate them, as well as what effects and benefits they will bring (Sikorski, 2006).

\section{RESEARCH RESULTS}

To carry out this work, empirical research was undertaken, which was conducted using a questionnaire in the form of direct contact. A survey is a method whose preparation and conducting does not lead to excessive disturbance of the natural mode of operation of the examined units.

The size of the research sample for a proper study was determined on the basis of consultations on the expected precision and representativeness of the assessments, and it amounted to approximately 400. The study involved persons in an industrial enterprise and a public utility entity. The applied questionnaire was anonymous. For the needs of this work, selected issues were investigated.

The following scale was used in the questionnaire: 1. I strongly disagree, 2. I rather disagree, 3 . I have no opinion, 4 . I rather agree, 5 . I definitely agree.

The institution in which $\mathrm{i}$ am employed takes actions aimed at increasing the level of cooperation between co-workers

Figure 1 presents the answers to the question - the institution in which I am employed takes actions aimed at increasing the level of cooperation between co-workers. 

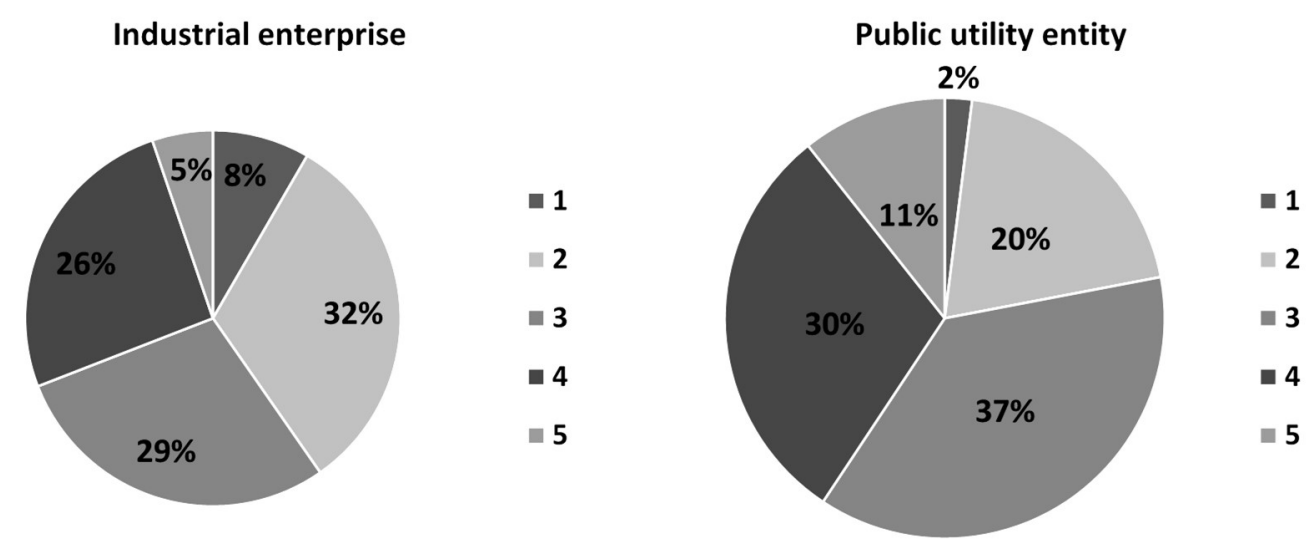

Fig. 1 Distribution of responses to the question: The institution in which I am employed takes actions aimed at increasing the level of cooperation between coworkers

In the industrial enterprise, negative responses constitute the largest percentage $-40 \%$ (at levels 1 and 2); this may mean that there is an irregularity in this area, which is why this aspect requires additional analysis. On the other hand, in the public utility entity, the most - around $40 \%$ - are positive answers (at levels 4 and 5). In both the studied facilities about $30 \%$ of employees did not give a definite answer to the question (answer at level 3). This may mean that these employees do not have sufficient knowledge about the management's actions to increase the level of cooperation between co-workers.

The analysis of data regarding the distribution of responses to the analyzed question regarding the length of employment of the employees showed that in the industrial enterprise the majority of employees from the length of employment ranges, up to 1 year, from 2 to 5 years, from 6 to 10 and from 11 to 20 , gave answers at levels 2 and 3 . On the other hand, in the length of employment range over 20 years, the respondents gave the most answers at level 4. In the public utility entity, only employees with employment over 20 years rated the analyzed issue well. In the remaining length of employment ranges, the highest number of respondents gave answers at level 3.

The data on the distribution of responses to the question under consideration, based on the age of the employees showed that in the industrial enterprise in the age brackets up to 25 years, from 26 to 30 , from 30 to 40 and from 40 to 50 years most employees negatively assessed the analyzed issue (responses at levels 2 and 3). However, in the age group above 50 years, the majority of respondents positively assessed the examined phenomenon (at level 4). In the public utility entity, the respondents from the age groups up to 25 years and over 50 years rated well the actions taken by the management in order to increase the level of cooperation between employees (the majority of responses at level 4). However, in the remaining age ranges, the employees did not have an opinion on the subject of the examined phenomenon (responses at level 3).

The conducted research using the chi-square independence test, at the significance level of $\alpha=0.01$, allowed the authors to state a dependence existing between the assessment of undertaken activities aimed at increasing the level of cooperation between employees and the age of employees in both the industrial enterprise and public utility entity. The value of the Pearson correlation 
coefficient was 0.41 and 0.45 respectively, which allows the authors to determine a correlation between these variables.

The success of any enterprise depends on effective communication and cooperation of employees, therefore decision-makers should take actions aimed at increasing efficiency and avoiding conflicts between employees. Communication at the appropriate level allows one to establish professional cooperation and affects the smooth functioning of the team of employees, thanks to which the company can effectively achieve its goals and develop.

\section{In my workplace, we often exchange information and experiences with our co-workers}

Figure 2 presents the distribution of replies to the question - in my workplace, we often exchange information and experiences with our co-workers. The analysis allows the authors to conclude that in both analyzed units, an advantage of scores of 4 and 5 was observed in this area, which may indicate the satisfaction of employees with the current level of information and experience exchange.
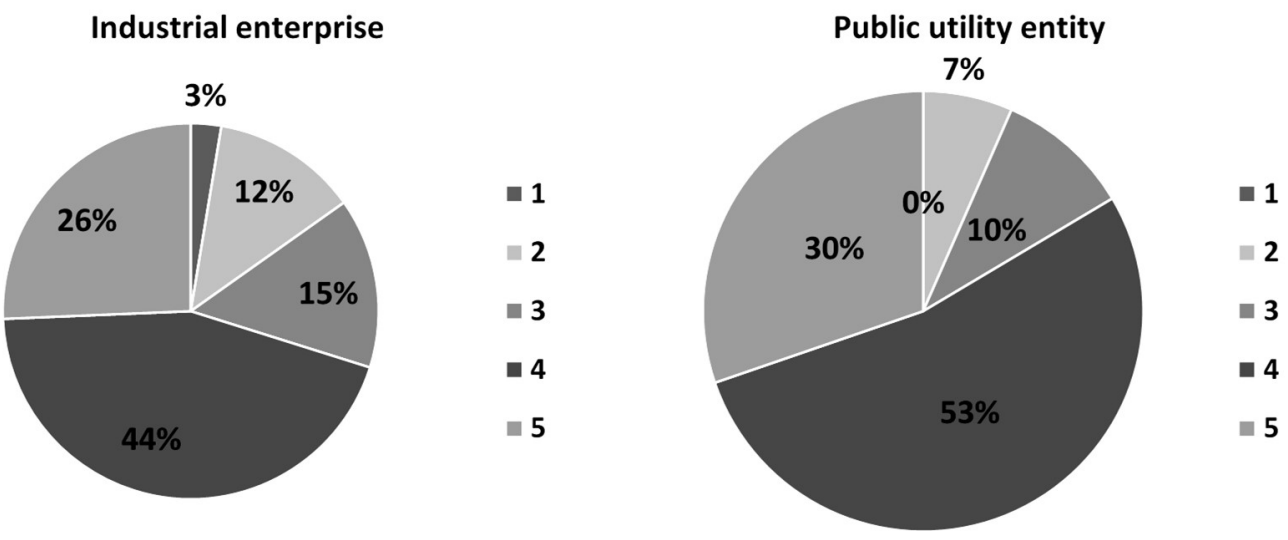

Fig. 2 Distribution of answers to the question: In my workplace, we often exchange information and experiences with our co-workers

Interpretation of the data concerning the distribution of responses to the analyzed question regarding the length of employment of the employed people showed that in both the analyzed units in all the age ranges, the employees positively evaluate the examined phenomenon (responses at levels 4 and 5). The distribution of responses to the analyzed question regarding the age of the employees allows the authors to state that in the industrial enterprise and in the public utility entity, answers at levels 4 and 5 dominate. This may be evidence of the good flow of information and experience between employees.

\section{My superior understands the need for information exchange between employees and takes steps to facilitate this process}

Figure 3 presents the distribution of responses to the question - my supervisor understands the need for information exchange between employees and takes actions to facilitate this process. 
Industrial enterprise

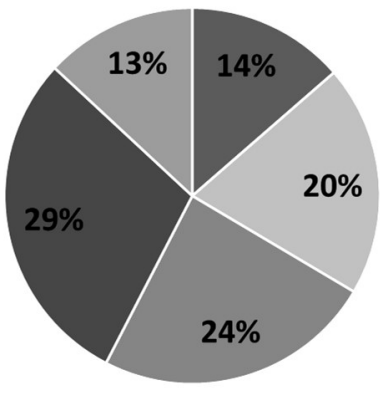

Public utility entity

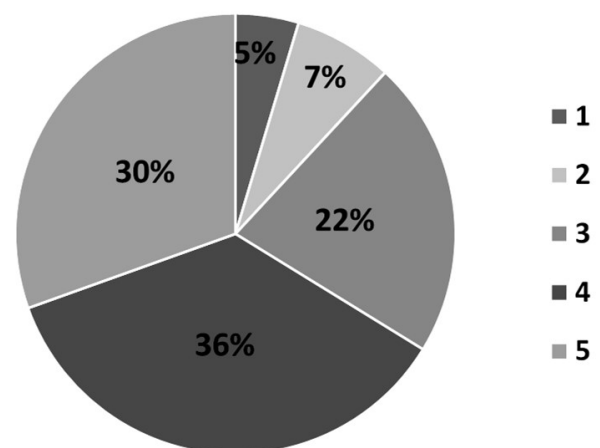

Fig. 3 Distribution of responses to the question: My supervisor understands the need for information exchange between employees and takes actions to facilitate this process

The conducted analysis allows the authors to conclude that in both analyzed units the employees evaluate the issue well (industrial enterprise $42 \%$, public utility entity $66 \%$ positive answers).

The data regarding the distribution of responses to the analyzed question in terms of the length of employment of the employed persons allow the authors to state that in the industrial enterprise there is a large scatter of answers in individual groups. In the length of employment bracket up to 1 year, from 6 to 10 years and over 20 years, the respondents rated the phenomenon well, while in the remaining length of employment groups, the respondents did not notice that their supervisor understood the need to exchange information between employees or undertook actions to facilitate this process. In the public utility entity, the employees in the all length of employment ranges positively assessed their superior in terms of understanding the need for information exchange and taking actions to facilitate this process (responses at levels 4 and 5).

The results of the analysis of the distribution of responses to the analyzed question, based on the age of the employee, allowed the authors to state that in the industrial enterprise in the age groups from 26 to 30 , from 40 to 50 and above 50, the employees assessed the assessed the issue well (grades of 4). However, in the public utility entity, the majority of employees from the age ranges up to 25 , from 26 to 30 , from 40 to 50 and over 50 years rated this issue at levels 4 and 5.

\section{After completing training, the employee is encouraged to share knowledge with his co-workers}

Figure 4 presents the distribution of replies to the question - after completing training, the employee is encouraged to share knowledge with his co-workers. There is a large spread of answers in the industrial enterprise, $26 \%$ of employees say that they are not motivated to share their knowledge, 35\% of employees on the contrary think that they are mobilized, and the most, because $39 \%$ of respondents, did not have an opinion. However, in the public utility entity, the highest percentage of employees, $63 \%$, confirms that they are encouraged to share with co-workers the knowledge gained during training. 
Industrial enterprise

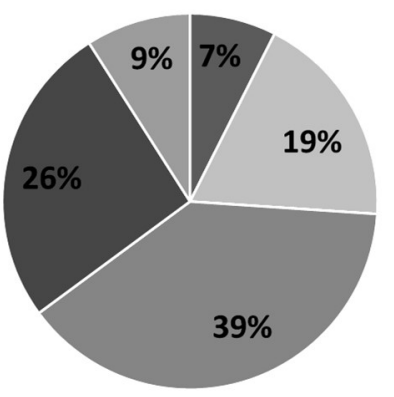

Public utility entity

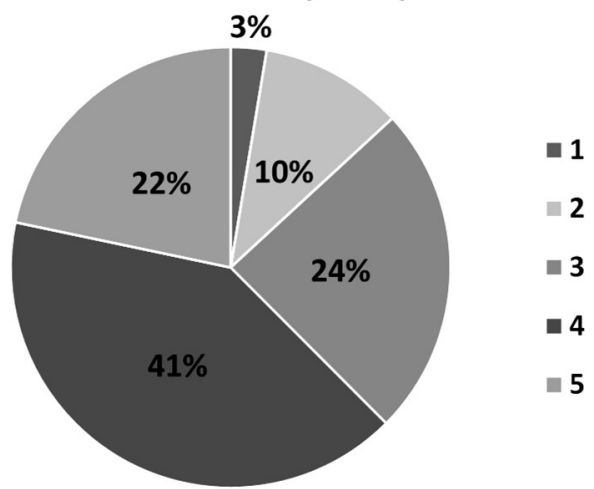

Fig. 4 Distribution of replies to the question: After completing training, the employee is encouraged to share knowledge with his coworkers

The analysis of the data regarding the distribution of responses to the analyzed question in terms of the length of employment of the employed persons showed that in the industrial enterprise the length of employment does not significantly influence the analyzed issue since a significant number of employees gave the answer "I have no opinion". In contrast, in the public utility entity in the length of employment range up to 1 year, the majority of respondents did not give an unambiguous answer (I have no opinion), in the remaining length of employment ranges, the majority confirmed that they are encouraged to share the knowledge gained during the training (answers at level 4).

The data concerning the distribution of responses to the analyzed question, regarding the age of the employed persons, showed that in the industrial enterprise there is a similar situation as in the analysis of this issue in terms of the length of employment of the employees, this means that the age of employees does not significantly influence the analyzed issue. In the public utility entity, the respondents mostly confirm that they are motivated to share knowledge gained during training (answers at levels 4 and 5).

Efficient knowledge management is of great importance in business management as it affects an increase in employees' knowledge and thus an increase in human resources potential, thanks to which the company can develop. The culture of sharing knowledge is a condition for innovative functioning of the enterprise.

\section{The training system is monitored in order to determine its effectiveness and modify future activities}

Figure 5 presents the distribution of answers to the question - the training system is monitored in order to determine its effectiveness and modify future activities. After the conducted analysis, it can be observed that in both units the employees did not express their opinions on the control of the training system, as the highest percentage of answers is, "I have no opinion" (industrial company $42 \%$, public utility entity $50 \%$ ).

Interpretation of the data regarding the distribution of responses to the analyzed question in terms of the length of employment and age of the employed persons allows the authors to conclude that in both the analyzed entities, the length of 
employment and age do not significantly affect the analyzed issue because the largest number of employees gave the answer "I have no opinion" (assessment at level 3).
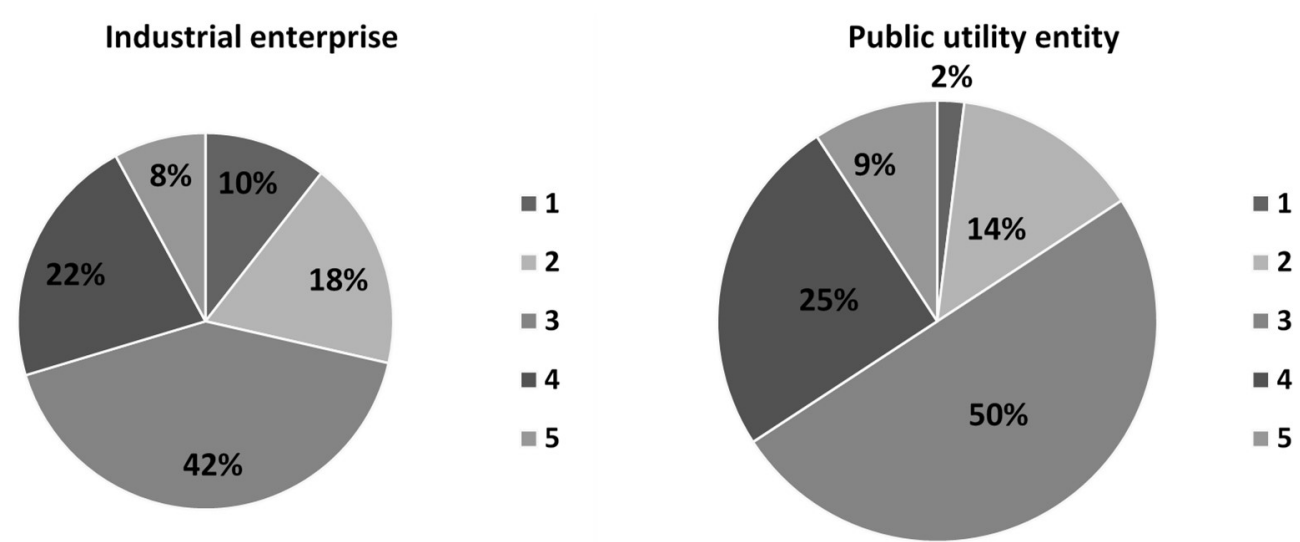

Fig. 5 Distribution of responses to the question: The training system is monitored in order to determine its effectiveness and modify future activities

Evaluation of the effectiveness of the training system is the last stage of the training process. The conducted research shows that in the analyzed entities this stage is not fully implemented, which adversely affects the activities of these units. It is this analysis that allows one to confirm or deny the essence of the training and to modify this system so that it increases the possibility of achieving the company's goals.

In the institution in which $\mathrm{i}$ am employed, activities are carried out to preserve acquired knowledge and experience

Figure 6 presents the distribution of replies to the question - in the institution in which I am employed, activities are carried out to preserve acquired knowledge and experience. It should be stated that in both the analyzed units, the largest number of employees confirmed that in their workplace such activities are carried out (in the industrial enterprise $43 \%$, in the public utility entity $54 \%$ ).
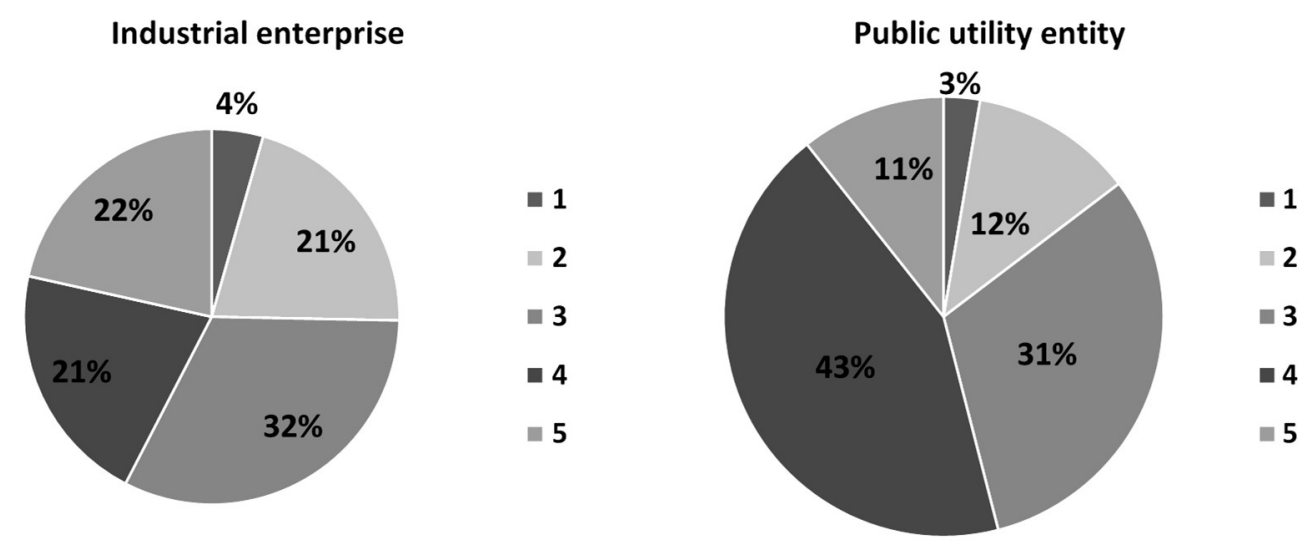

Fig. 6 Distribution of answers to the question: In the institution in which I am employed, activities are carried out to preserve the acquired knowledge and experience 
In addition, in these units the respondents gave about $30 \%$ of replies at level 3 , which may mean that the employer does not conduct sufficient activities to consolidate the acquired knowledge and experience of employees.

The results of the analysis of data on the distribution of responses to the analyzed question regarding the length of employment of the employed people showed that in the industrial enterprise in the length of employment ranges up to 1 year, from 2 to 5 years and over 20 years of work, a significant proportion of employees confirm that in their workplace activities aimed at preserving the acquired knowledge and experience are carried out. However, in the public utility entity this thesis is confirmed by the majority of employees from the ranges up to 1 year, from 2 to 5 years, from 11 to 20 years and over 20 years of work.

The data regarding the distribution of responses to the analyzed question in terms of the age of the employees allowed the authors to conclude that in the industrial enterprise, the majority of employees in the age ranges from 26 to 30 , from 40 to 50 and over 50 years agree with the statement. In the public utility, most employees from the age ranges up to 25 , from 26 to 30 , from 40 to 50 and over 50 years also agree with this claim.

The conducted research using the chi-square independence test, at the significance level of $\alpha=0.01$, allowed the authors to state a dependence existing between the assessment of the conducted activities aimed at preserving the acquired knowledge and experience with the age of the employees. The calculated value of the Pearson correlation coefficient was 0.4 , which allows the authors to conclude that there is a correlation in the industrial enterprise between the analyzed variables.

\section{CONCLUSION}

When asked about actions taken to increase the level of cooperation between co-workers in the industrial enterprise, answers at level 1 and 2 were provided by $40 \%$ of the respondents, the reverse situation is noted in the public utility entity, where approx. $40 \%$ of respondents gave answers at levels 4 and 5 . In both facilities about $30 \%$ of respondents did not give a clear answer (answer at level 3).

In the case of the question regarding the exchange of information and experience with their co-workers, in both facilities, assessments at levels 4 and 5 constitute $70 \%$ (industrial enterprise) and $83 \%$ (public utility entity).

To the question - my supervisor understands the need for information exchange between employees and undertakes activities aimed at facilitating this process, in the industrial enterprise $42 \%$ of respondents gave answers at levels 4 and 5 , on the other hand, this aspect was much better assessed by employees of the public entity $-66 \%$ of the answers were at levels 4 and 5 .

When asked about sharing knowledge gained from completed training with coworkers, in the industrial enterprise the most responses were at level 3 (I have no opinion) $-39 \%$, in the public utility entity about $60 \%$ of respondents gave answers at levels 4 and 5 . 
In the case of the question regarding monitoring the training system in order to determine its effectiveness and modification of future activities, in both facilities the most answers appeared at level 3 (I have no opinion) $-42 \%$ (industrial enterprise) and $50 \%$ (public utility).

To the question - in the institution in which I am employed, activities aiming at preserving the acquired knowledge and experience in an industrial enterprise $41 \%$ of respondents gave answers at levels 4 and 5 , while this aspect was better assessed by the employees of the public utility entity $-54 \%$ of answers were at levels 4 and 5 . It should be noted that in both facilities about $30 \%$ are answers "I have no opinion".

The analysis of the survey results presented in the paper allowed the authors to state that the management style the organization has a significant impact on shaping its organizational culture. The high frequency of choice of answer 3 (I have no opinion) may indicate the ignorance of employees related to the questionnaire.

\section{REFERENCES}

Cameron, K. S. and Quinn, R. E. (2006). Diagnosing and Changing Organizational Culture. Base on the Competing Values Framework. San Francisco: Jossey-Bass.

Chmielewska-Muciek, D. (2009). Dyskusja nad pojęciem kultury organizacyjnej. Annales Universitatis Marie Curie-Skłodowska Lublin-Polonia, 43 (20), pp. 317331.

Cieślicki, M. (2001). O zarządzaniu słów kilka. Gorzów Wielkopolski: Wyższa Szkoła Biznesu.

Hortoványi, L. (2012). Entrepreneurial Management. Corvinus University of Budapest Department of Strategic Management Published by AULA Kiadó Kft. [online] http:// mek.oszk.hu/11400/11406/11406.pdf (18.07.2019).

Kim, S. (2002). Participative management and job satisfaction. Public Administration Review, 62(2), pp. 231-241.

Kocher, M. G., Pogrebna, G. and Sutter, M. (2013). Other - regarding preferences and management styles. Journal of Economic Behavior \& Organization, 88, pp. 109132.

Kostera, M., Konwacki, S. and Szumski, A. (1998). Zachowania organizacyjne: motywowanie, przywództwo, kultura organizacyjna [in:] Koźmiński, A.K. and Piotrowski, W. (ed.), Zarządzanie. Teoria i praktyka. PWN, Warszawa.

Luthans, F. and Stajkovic, A. D. (1999). Reinforce for performance: the need to go beyond pay and even rewards. The Academy of Management Executive, 13(2), pp. 49-57.

Olmedo-Cifuentes, I. and Martinez-Léon, I. M. (2014). Influence of management style on employee view of corporate reputation. Applications to audit firms. BRQ Business Research Quarterly, 17(4), pp. 223-241.

Panasiewicz, L. (2013). Ukryta przewaga. Kultura organizacyjna jak czynnik sukcesu współczesnych przedsiębiorstw. Lublin: Wydawnictwo Politechniki Lubelskiej.

Penc, J. (1997). Leksykon biznesu. Warszawa: Agencja Wydawnicza Placet,

Penc, J. (2000). Kreatywne kierowanie. Warszawa: Agencja Wydawnicza Placet.

Perechuda, K. ed. (2000). Zarządzanie przedsiębiorstwem w przyszłości. Koncepcje, modele, metody. Warszawa: Agencja Wydawnicza Placet.

Rolková, M. and Farkašová V. (2015). The features of participative management style. Procedia Economics and Finance, 23, pp. 1383-1387.

Schein, E. H. (2004). Organizational Culture and Leadership. San Francisco: JosseyBass.

Sikorski, C. (2006). Kultura organizacyjna. Warszawa: C.H. Beck. 
Srivastava, N. and Agrawal, A. (2010). Factors supporting corporate entrepreneurship: an exploratory study. The Journal of Business Perspective, 3 (14), pp. 163-171.

Stańczyk, S. (2008). Nurt kulturowy w zarządzaniu. Wrocław: Uniwersytet Ekonomiczny.

Tohidi, H. and Jabbari, M. (2012). Organizational culture and leadership. Procedia Social and Behavioral Sciences, 31, pp. 856-860.

Walecka, A. (2013).Style kierowania zespołami pracowniczymi podczas kryzysu w przedsiębiorstwie. Zeszyty Naukowe Politechniki Łódzkiej Organizacja i Zarządzanie, 1144, pp. 139-148.

Zehir, C., Ertosun, O., Zehir, S. and Muceldili, B. (2011). The Effects Of Leadership Styles And Organizational Culture Over Firm Performance: Multi-National Companies in Istanbul. Procedia Social and Behavioral Sciences, 24, pp. 14601474.

Żukowski, P. and Galla, R. (2009). Style kierowania przejawiane przez menedżerów w zarządzaniu organizacją. Problemy profesjologii, 1, pp. 21-40.

\begin{abstract}
.
The basis for the functioning of every organization and achieving the set goals are employees. It is they who shape the image, create the organizational culture and reputation of the company in the environment. Their competences, knowledge and skills determine the efficiency and effectiveness of the organization's operations. Thanks to their work, products and services are created that meet social needs and thus organizational progress. The aim of this work was to conduct research on the organization's ability to identify and retain the best employees, the ability to promote desired attitudes and behaviors, as well as to create a friendly and rewarding work environment that are key factors for business success. Updating the knowledge possessed by employees and developing new skills is often crucial in keeping the organization on the market.
\end{abstract}

Keywords: management styles, organizational culture, human resource management 